\title{
Insights on The Morphological and Phylogenetic Delimitation of Dacrymyces Nees
}

Renato Lúcio Mendes Alvarenga ( $\nabla$ renatolma@gmail.com )

Universidade Federal de Pernambuco https://orcid.org/0000-0003-0400-3762

Tatiana Baptista Gibertoni

Universidade Federal de Pernambuco

\section{Research Article}

Keywords: Atlantic Rainforest, Amazon Forest, Brazil, Heterobasidiomycetes, New taxa

Posted Date: December 1st, 2021

DOl: https://doi.org/10.21203/rs.3.rs-950799/v1

License: (9) This work is licensed under a Creative Commons Attribution 4.0 International License. Read Full License 


\section{Abstract}

Dacrymycetes has four families and 13 genera, few of them with molecular data available and then usually polyphyletic in phylogenetic analyses. Dacrymyces Nees is one of the polyphyletic genera in Dacrymycetes and it was introduced to accommodate one species, D. stillatus Nees. The morphological features of the genus are a homogeneous composition of the intra-structure and an amphigenous or superior hymenium. In this study, we included Neotropical specimens in the phylogeny of the Dacrymycetes and Dacrymyces s.s. is emended to include species with resupinate basidiomata, unilateral hymenium and heterogeneous context. In this new delimitation, the new species Dacrymyces flavobrunneus is described using morphological and molecular data and three new combinations $(D$. ceraceus comb. nov., D. maxidorii comb. nov. and D. spathularia comb. nov.) are proposed based on DNA analyses.

\section{Introduction}

Dacrymycetes is a class of Basidiomycota characterized by the presence of continuous parenthosomes covering the dolipore septa (Oberwinkler 1993, Wells 1994), long bifurcate basidia, except in Unilacryma unispora (L.S. Olive) Shirouzu, Tokum. \& Oberw., and basidiospores normally septate (McNabb 1964; 1965a-e;1966; Shirouzu et al. 2013a; Oberwinkler 2014). Mostly of the species are brown-rot (Oberwinkler 1993), although white-rot was also reported (Seifert 1983).

Currently, Dacrymycetes has four families (Cerinomycetaceae, Dacrymycetaceae, Dacryonaemataceae and Unilacrymaceae), all with morphological and molecular support (Zamora and Ekamn 2020), and 13 genera [Arrhytidia Berk. \& M.A. Curtis, Calocera (Fr.) Fr., Cerinomyces G.W. Martin, Dacrymyces Nees, Dacryomitra Tul. \& C. Tul, Dacryonaema Nannf., Dacryopinax G.W. Martin, Dacryoscyphus R. Kirschner \& Zhu L. Yang, Ditiola Fr., Femsjonia Fr., Guepiniopsis Pat., Heterotextus Lloyd, and Unilacryma Shirouzu, Tokum. \& Oberw.] that are mainly delimited based on morphological features (Oberwinkler 2014). Four genera (Calocera, Cerinomyces, Dacryopinax and Dacrymyces) in Dacrymycetes have molecular data available and they are usually polyphyletic in the phylogenetic analyses (Shirouzu et al. 2013a; Zamora and Ekamn 2020).

Dacrymyces was introduced to accommodate one species, D. stillatus Nees (1816), which presented teleomorphic and anamorphic stage. The morphological features of the genus are a homogeneous composition of the intra-structure, and an amphigenous or superior hymenium (McNabb 1973). The last revision of the genus was performed by $\mathrm{McNabb}$ (1973) using morphological features and included 31 species in Dacrymyces. Currently, the genus has 131 species names in Index Fungorum, although some of these were considered invalid or synonymized by McNabb (1973).

Recently, some Dacrymyces species have been described using molecular and morphological data (Shirouzu et al. 2009, 2017). So far, 29 species have DNA sequences usually from ITS and nc LSU rDNA regions (Shirouzu et al. 2009, 2017; Zamora and Ekamn 2020). For example, Zamora and Ekamn (2020) 
showed that the molecular, morphological, cytological and secondary compounds data produced similar phylogenies and, for some species complexes (e.g., Calocera cornea complex or D. stillatus complex), the inclusion of different approaches would be important to delimit these species.

In the Neotropics, the genus is represented by 12 species [D. ancoratus Lowy, $D$. bambusae Rick, $D$. capitatus Schwein., D. ceraceoides Rick, D. chrysospermus Berk. \& M.A. Curtis, D. dictyosporus G.W. Martin, D. enatus (Berk. \& M.A. Curtis) Massee, D. falcatus Brasf., D. punctiformis Neuhoff, D. stillatus, D. subtristis Rick, D. variisporus McNabb] (Lowy 1971; Sobestiansky 2005; Meijer 2006; Alvarenga and Xavier Santos 2017; Castro-Santiuste et al. 2017), although none of them was confirmed using molecular data and mostly represented by one record. Thus, the aim of the study was to expand the knowledge of Dacrymyces s.s. clade based on morphology features and phylogenetic inferences, to describe one new species, and to propose three new combinations.

\section{Material And Methods}

Studied area and morphological analysis

The specimens were collected during the rainy season in the Atlantic Rain Forest (Pernambuco state, Brazil) and Amazon Forest (Amazonas state, Brazil). Microscopical studies were made with preparations mounted in $3 \% \mathrm{KOH}+1 \%$ phloxine, Melzer reagent and cotton blue. Measures followed Miettinen et al. (2012). The following abbreviations were used in morphological descriptions and tables: $L=$ mean spore length, $\mathrm{W}=$ mean spore width, $\mathrm{Q}^{\prime}$ = length/width ratio, $\mathrm{Q}=$ mean length/width ratio, $\mathrm{n}$ = number of measurements per specimen. Color followed Kornerup \& Wanscher (1978) and the literature used for identification was Lowy $(1971,1981)$, Alvarenga and Xavier Santos (2017) and Castro-Santiuste et al. (2020). The specimens are deposited in the Herbarium (URM) of the Departamento de Micologia ate the Universidade Federal de Pernambuco (UFPE) and isotypes in the Herbarium (SP-Fungi) of the Instituto de Pesquisas Ambientais do Estado de São Paulo (Thiers 2016).

DNA extraction, PCR amplification and sequencing

DNA extraction was performed with the DNeasy Plant Mini Kit (Qiagen), following the manufacturer's protocol. Polymerase chain reaction (PCR) was performed to amplify the ITS and nc 28S LSU using the primers ITS1/ITS4 (White et al. 1990; Gardes and Bruns 1993) and LROR/LR5 (Vilgalys and Hester 1990), respectively. Polymerase chain reaction (PCR) products were purified applying the ExoSAP-IT (Thermo Fisher Scientifc). We used the same primer pairs for amplicon sequencing following the manufacturer's instructions of the BigDye Terminator Cycle Sequencing Kit v.3.1. The sequences were provided by the Plataforma Tecnológica de Genômica e Expressão Gênica do Centro de Biociências at the UFPE, Recife, Brazil.

Phylogenetic analyses 
The assembly and editing of sequences were performed in Staden Package 2.0 software (Staden et al. 1998) and MEGA v. 6 (Tamura et al. 2013). Sequences were used to compare with sequences deposited in GenBank of the NCBI. Sequences obtained in this study were deposited in GenBank. For alignments, we followed Shirouzu et al. (2017) and Castro-Santiuste et al. (2020) and included the new sequences from our specimens (Table 1). Sequence alignments were constructed using the online version of MAFFT (Katoh and Toh 2008), using the Q-INS-I option with default parameters. Ambiguously regions in the alignment (e.g., large gaps) were manually removed prior to subsequent analysis.

Phylogenetic reconstructions were inferred by Maximum Likelihood $(\mathrm{ML})$ and Bayesian Inference $(\mathrm{BI})$. The best evolutionary model was estimated for the ITS and nc LSU rDNA datasets based on Bayesian Information Criterion (BIC) using W-IQ-TREE (Kalyaanamoorthy et al. 2017). ML analysis was performed in W-IQ-TREE (Trifinopoulos et al. 2016), using the SYM+l+G4 model, with 1000 bootstrap replicates (Nguyen et al. 2015) and Ultrafast bootstrap (UFBoot2, Hoang et al. 2017). Bl analysis was performed in MrBayes v.3.1.2 (Ronquist and Huelsenbeck 2003) by using SYM+I+G as the best model for two independent runs, each with four chains and run for 10 million generations (split frequence $=0.008$ ). The convergence of the runs was checked using TRACER v1.7.1 (Rambaut et al. 2018).

Statistical support for branches was considered informative with Bayesian posterior probabilities (pp) $\geq 0.95$ and bootstrap (bs) and UFBoot2 (ub) values $\geq 70 \%$. The trees were visualized with FigTree (Rambaut 2014) and the final layout made in Inkscape 2020.

\section{Results}

Phylogenetic reconstruction was based on the alignment of the ITS+nLSU dataset (1282 characters, including gaps) of 141 sequences representing eight genera belonging to Dacrymycetes. $\mathrm{ML}$ and $\mathrm{BI}$ analyses produced trees with nearly congruent topologies and therefore only the ML tree is shown (Fig. 1). The sequences from the studied specimens were grouped within a clade with high support ( $b p=98$, $\mathrm{ub}=91$ and $\mathrm{pp}=0.99$ ), which we treated as the Dacrymyces sensu stricto clade.

The Dacrymyces s.s clade comprises 18 species, including the specimens studied in the current work: the new species $D$. flavobrunneus $(\mathrm{bp}=100, \mathrm{ub}=100, \mathrm{pp}=1)$ and the new combination $D$. maxidorii $(\mathrm{bp}=$ $98.1, \mathrm{ub}=100, \mathrm{pp}=1$ ). In addition, sequences of materials previously identified as species of Cerinomyces [C. ceraceus Ginns, C. lagerheimii (Pat.) McNabb and C. grandinioides McNabb], as Guepiniopsis buccina (Pers.) L.L. Kenn. and as Dacryopinax spathularia (Schwein.) G.W. Martin] clustered with high support in this clade $(b p=100, u b=100, p p=1)$ and, except for the sequences identified as $C$. lagerheimii, C. grandinioides and G. buccina, were transferred to Dacrymyces.

\section{Taxonomy}

Dacrymyces Nees [as ' Dacryomyces'], emend. Alvarenga

MycoBank: MB17455 
Description: Basidiomata originating as pustules, becoming pulvinate discoid, subglobose, lobed, cerebriform turbinate, pezizoid or resupinate, often stipitate becoming spathulate to flabellate, usually attached to substratum by a point or rooting base, occasionally broadly attached. Consistency soft gelatinous to firm gelatinous. Context hetero or homogeneous, gelatinized, clamp connections absent. Cortex present or absent, when present composed of a palisade of thin or thick-walled, septate hairs, terminal cells cylindrical, subclavate, ovate, globose to sub-globose or obpyriform. Hymenium amphigenous, superior or unilateral. Basidia cylindrical-subclavate, occasionally obclavate or urniform, becoming bisterigmated. Dikaryophyses (hyphidia) present or absent. Basidiospores cylindrical, curved cylindrical, allantoid, occasionally broadly and bluntly fusiform, ovate or sub-globose, apiculate, septate at maturity. Germination by conidia and/or germ tubes.

Type species: Dacrymyces stillatus Nees, Syst. Pilze (Würzburg): 89 (1816) [1816-17].

Remarks: Dacrymyces is traditionally recognized by the homogeneous composition of the intra-structure and an amphigenous hymenium (McNabb 1973). Previously, the species with unilateral hymenium were placed in Dacryopinax, with a heterogeneous composition in Ditiola, and resupinate in Cerionomyces (McNabb 1964, 1965a, 1966, 1973). However, the morphological features do not agree with the phylogenetic analyses, and it cannot be used separately to recognize or distinguish the genera in Dacrymycetaceae (Shirouzu et al. 2013, 2017; Zamora and Ekamn 2020).

Based on our phylogenetic analyses (Fig. 1), species with resupinate basidiomata, heterogeneous composition of the context and unilateral hymenium are grouped in the Dacrymyces s.s. clade clade with high support $(b p=100, u b=100, p p=1)$. Thus, we emend the genus description to comprise species with these morphological features.

Dacrymyces flavobrunneus Alvarenga sp. nov., Fig. 2

\section{MycoBank: MB841253}

Etymology: flavobrunneus (Lat.) = Adj. "flavus-" referring to yellow basidioma when fresh; Adj. "brunneus" referring to brown basidioma when dry.

Holotype: BRAZIL: Rondônia, Estação Ecológica de Cuniã. Angelina Meiras-Ottoni,11 Feb. 2017, AMO789, (URM). GenBank: ITS = OK257533, LSU = OK257540.

Description: Basidiomata 3-24 mm long, pileate-stipitate, cartilaginous, orange (6A7) when fresh, yellow brown (6F7) when dry. Pileus 3-13 mm in diameter, spathulate; sterile side velutinous, with pale white to brownish hairs. Stipe up to $10 \times 1-2 \mathrm{~mm}$, cylindrical, central, velutinous, with greyish hairs when dry. Hymenium unilateral, smooth, glabrous. Marginal hyphae (hairs) of stipe and abhymenium hyphae (abhymenium hairs), $15 \mu \mathrm{m}$ wide, globose to subglobose, pyriform, septate, thick-walled $(4 \mu \mathrm{m})$, hyaline to yellowish. Context gelatinized, heterogeneous with two types of hyphae: thin-walled, $1.2-3.0 \mu \mathrm{m}$ 
diameter, and thick-walled, 4-5(-7) $\mu \mathrm{m}$ diameter, both branched, septate, without clamp connections. Basidia 20-27 × 3-4 $\mu \mathrm{m}$, cylindric to clavate, becoming bifurcate when mature; sterigmata up to 7-11 $\mu \mathrm{m}$, often collapsed after spores' liberation, hyaline, guttulate (carotenoid pigments), hyphidia absent or mixed into the hymenium. Basidiospores (7-) 9-10.3 (-11) × (2.8-) 3.2-4 (-4.2) $\mu \mathrm{m}, \mathrm{Q}=2.33-3.66, \mathrm{Q}^{\prime}$ $=2.89, \mathrm{~L}=9.38, \mathrm{~W}=3.24$, ellipsoid to allantoid slight curved, aseptate to 1-septate, hyaline, guttulate, smooth.

Remarks: The new species $D$. flavobrunneus is similar to $D$. maxidorii, but it can be differentiated by the spathulate pileus, globose to subglobose hairs, heterogenous context, absence of hyphidia and smaller basidia $(30-36.5 \times 4.5 \mu \mathrm{m})$ (Lowy 1981). Dacrymyces flavobrunneus differs from other species in Dacrymyces due to the unilateral hymenium and heterogeneous context.

Distribution: This specie is known so far from the Brazilian Amazon Forest.

Material examined: Brazil: Amazonas, Presidente Figueiredo, Gruta da Judeia, Tatiana B. Gibertoni, 21 July 2019, DNA21025 (URM); Ibid, Floresta Nacional do Jamarí. Angelina Meiras-Ottoni, 06 Feb. 2016, AM0703, (URM); Ibid, 17 Brigada de Infantaria de Selva. Angelina Meiras-Ottoni, 20 Dec. 2016, AM0721 (URM).

Dacrymyces ceraceus (Ginns) Alvarenga, comb. nov.

MycoBank: MB841254

Basionym: Cerinomyces ceraceus Ginns, Canadian Journal of Botany 60 (4): 519 (1982) [MB110534] Description: Ginn (1982).

Remarks: Dacrymyces ceraceus can be easily recognized by the resupinate basidiomata, presence of spines on hymenophore, basidiospores $12-17 \times 4.5-5(-6) \mu \mathrm{m}$ and with $0-3$ septa. The species was originally collected in the USA and the available sequences are from the holotype (Ginn 1982).

Distribution: This species is only known from the USA.

Dacrymyces maxidorii (Lowy) Alvarenga, comb. nov.

MycoBank: MB841255

Basionym: Dacryopinax maxidorii Lowy, Mycotaxon 13 (2): 428 (1981) [MB112260]

Description: Lowy (1981).

Remarks: Dacrymyces maxidorii is characterized by the presence of cylindrical hairs with globose to subglobose inflated parts forming chains in abhymenial surface (Lowy 1981). In Dacrymycetaceae, four species have inflated abhymenial hairs (Dacryopinax indacocheae Lowy, Dacryopinax primogenitus D.J. McLaughlin \& E.G. McLaughlin, Dacryopinax lowyi S. Sierra \& Cifuentes, and Dacrymyces flavobrunneus 
Alvarenga), all with Neotropical distribution, although only D. flavobrunneus is, so far, phylogenetically close to this species (Fig. 1).

Dacryopinax indacocheae was described using samples from Bolivia and differs from Dacrymyces maxidorii due to presence of conidiophore in the basidiomata (Lowy 1959). Dacryopinax lowyi was described from material collected in Mexico and has larger spores $(13-17 \times 5.6-7.5 \mu \mathrm{m})$ with 3 septa when mature (Sierra \& Cifuentes 2005), while D. maxidorii has smaller spores [(7.0-) 8-10 (-11.0) × 4.5$5 \mu \mathrm{m}]$ and 1 septum (Lowy 1981). Dacryopinax primogenitus is a recently described species from Costa Rica and it was the first Dacrymycetes to have its genome sequenced. The species differs from the Brazilian's species due to the smaller pileus and few inflated cells in the abhimenial surface (Mclaughlin et al. 2016).

Distribution: This species is so far recorded only in Brazil in almost all Brazilian's biomes (Amazon Forest, Atlantic Forest and Cerrado).

Material examined: Brazil: Acre, RESEX Cazumbá-Iracema/Sena Madureira. Angelina Meiras-Ottoni, 11 April 2019, AM01396 (URM); Pernambuco, Reserva Biológica de Pedra Talhada. Renato L. M. Alvarenga, 10 July 2017, RLMA479 (URM); Ibid, leg., 10 July 2017, RLMA480 (URM); Ibid, leg., Vitor Xavier de Lima, 14 May 2018, VXLF58 (URM); Ibid, leg., 25 June 2018, VXLF320 (URM); Ibid, leg., 06 July 2017, JPT02 (URM); Reserva Ecológica de Saltinho. Angelina Meiras-Ottoni, 15 May 2018, AM01156 (URM); Ibid, leg., 11 April 2016, RLMA305 (URM); Ibid, leg., 11 April 2016, RLMA306 (URM); Rondônia: Parque Natural de Porto Velho. Angelina Meiras-Ottoni, 03 Jan. 2018, AM0877 (URM); Ibid, leg., 16 Jan. 2016, AM0510 (URM); Sergipe: Parque Nacional da Serra de Itabaiana. Cléverton Oliveira Mendonça 15 June 2018, DNA21031 (URM).

Dacrymyces spathularia (Schwein.) Alvarenga, comb. nov.

MycoBank: MB841256

Basionym: Merulius spathularius Schwein., Schriften der Naturforschenden Gesellschaftzu Leipzig 1: 92 (1822) [MB208187]

Description: Martin (1948) and McNabb (1965a).

Remarks: Dacrymyces spathularia differs from other Dacrymyces species by the pileate-stipitate basidiomata, with a spatulate to flabelliform pileus, unilateral hymenium, homogenous context, thickwalled hypha, cylindrical abhymenial hairs and basidiospores with (7)8-10.5(11.5) × 3.5-4(4.5), 0-1 septa (McNabb 1965b). The species was described using samples from the USA.

Distribution: This species is recorded in tropical and subtropical regions (GBIF 2021).

\section{Discussion}


In our study, the Dacrymyces s.s. clade is phylogenetically separated from the Calocera s.s. and Dacryopinax s.s. clades (bs $=98, \mathrm{ub}=91$, $\mathrm{pp}=0.99$ ) as well as from other sequences of material identified as Dacrymyces. Usually, species in Dacrymycetes with amphigeneous or superior hymenium are placed in Dacrymyces; with unilateral hymenium are included in Dacryopinax, with coralloid basidiomata are described in Calocera, and resupinate species are treated in Cerinomyces. The tradition of using morphology to delimitate taxa continued up to recently (e.g., Shirouzu et al. 2009, 2013, 2017), including studies that used molecular data. However, evidences showed that the morphology does not agree with the phylogenetic history of the taxa (Shirouzu et al. 2013, 2017; Zamora and Ekamn 2020). Recently, Zamora and Ekamn (2020) showed similar results on the Dacrymyces s.s. clade, although they did not focus in this specific group.

Here, the combinations $D$. ceraceus, $D$. maxidori and $D$. spathularia are proposed based on phylogenetic data, as well as following comments of previous results (Shirouzu et al. 2013, 2017; Zamora and Ekamn, 2020). Other species clearly placed in the Dacrymyces s.s. clade, however, were not combined to this genus. Cerinomyces lagerheinii was described using samples from Ecuador, but the sequences available are from the USA. This species is reported in Brazil, Ecuador, French Polynesia, Mexico, New Zealand and Venezuela (GBIF 2021). A revision of these samples, older names, and sequencing of the type material or material from the type locality are desirable to know the truly distribution range and boundaries of the species. The sequences used to $C$. grandinioides and G. buccina are not either from their types materials or specimens collected in the type locality (Kenya and unknown locality in Europe, respectively), so those sequence may not represent the species (McNabb 1964, 1965b).

The Dacrymyces s.s. clade was phylogenetically well delimited and an emend to this genus is herein proposed to include species with resupinate basidiomata, unilateral hymenium and heterogeneous composition, following the morphological features of the new combinations and the new species. In addition, the knowledge about Dacrymyces richness in Brazil was updated to seven species by the addition of one new taxon and two combinations of previously described species. Therefore, the inclusion of specimens and sequences from samples collected in the Neotropics can be important to understand the morphological delimitation of Dacrymyces, as well as the knowledge about the Dacrymycetes diversity.

\section{Declarations}

\section{Acknowledgments}

The authors would like to thank Angelina Meiras-Ottoni, Cléverton Mendonça and Vitor Xavier de Lima for donations of collections, the Herbário Pe. Camille Torrend (URM) for the loan of the exsiccates, the Programa de Pós Graduação em Biologia de Fungos (UFPE, Brazil). We also would like to thank Nordesta Reforestation \& Education for support for field work at Biological Reserve of Pedra Talhada.

Funding - This research was funded by Conselho Nacional de Desenvolvimento Científico e Tecnológico (CNPq) [PQ 1D (307601/2015-3, 302941/2019-3), ICMBio 421241/2017-9] and FACEPE (BFP-0207- 
2.03/20 and APQ 0003-2.03/18).

Conflicts of interest/Competing interests (include appropriate disclosures) - Not applicable

Ethics approval - Not applicable

Consent to participate - Not applicable

Consent for publication - Not applicable

Availability of data and material - All material is deposited in Herbarium URM. The sequences ares deposited in GenBank. Data will be available online after the acceptance of the manuscript in http://www.splink.org.br/ and https://www.ncbi.nlm.nih.gov/genbank/.

Code availability - Not applicable

Authors' contributions - All authors contributed to the study conception and design. Material preparation, data collection and analysis were performed by Renato Lúcio Mendes Alvarenga. The manuscript was written by all authors. All authors read and approved the final manuscript. Tatiana B. Gibertoni provided funds and supervised this research.

\section{References}

1. Alvarenga RL, Xavier-Santos S (2017) New records of Dacrymycetes (Fungi: Basidiomycota) from the Cerrado Biome (Brazilian Savanna) and Midwest Region, Brazil. Check List 13: 335-342. https://doi.org/10.15560/13.4.335

2. Castro-Santiuste S, Sierra S, Guzmán-Dávalos L, Cifuentes J, Evans T, Martínez-González R, Alvarado Sizzo H, Luna-Vega I (2020) Dacryopinax (Fungi: Dacrymycetales) in Mexico. Phytotaxa 446(1):006022. https://doi.org/10.11646/phytotaxa.446.1.2

3. Castro-Santiuste S, Sierra S, Guzmán-Dávalos L, Luna-Vega I (2017) A review of the taxonomy and species diversity in Dacrymycetes (Fungi, Basidiomycota) in Mexico. Nova Hedwigia 105: 365-384

4. Gardes M, Bruns T (1993) ITS primers with enhanced specificity for basidiomycetes: application to the identification of mycorrhizae and rust. Molecular Ecology 2: 113-

118. https://doi.org/10.1111/j.1365-294X.1993.tb00005.x

5. GBIF: The Global Biodiversity Information Facility (2021). Available from https://www.gbif.org/ [13 September 2021]

6. Ginns J (1982) Cerinomyces ceraceus sp. nov. and the similar $C$. grandinioides and $C$. lagerheimii. Can J Bot 60: 519-524, doi:10.1139/b82-069

7. Hoang DT, Chernomor O, Haeseler A von, Minh BQ, Vinh LS (2017) UFBoot2: Improving the ultrafast bootstrap approximation. Mol Biol Evol, in press. https://doi.org/10.1093/molbev/msx281 
8. Index Fungorum Partnership (2018) Available from:

http://www.indexfungorum.org/names/names.asp (accessed 09 September 2021)

9. Kalyaanamoorthy S, Minh BQ, Wong TKF, Haeseler A von, Jermiin LS (2017) ModelFinder: Fast model selection for accurate phylogenetic estimates. Nature Methods, 14:587-589. https://doi.org/10.1038/nmeth.4285

10. Katoh K, Rozewicki J, Yamada KD (2019) MAFFT online service: multiple sequence alignment, interactive sequence choice and visualization. Briefings in Bioinformatics 20: 1160- 1166. https://doi.org/10.1093/bib/bbx108

11. Kornerup A, Wanscher JH (1978) Methuen handbook of colour, 3rd edn. Eyre Methuen Ltd., London

12. Lowy B (1959)[1961] New or noteworthy Tremellales from Bolivia. Mycologia 51: 840-850. https://doi.org/10.2307/3755834

13. Lowy B (1971) Tremellales. Flora Neotropica, Monograph no. 6. Hafner, New York, 153 pp

14. Lowy B (1981) A new species in Dacryopinax from Brazil. Mycotaxon 13: 428-430

15. Martin GW (1948) New or noteworthy tropical fungi. IV. Lloydia 11: 111-122.

16. McLaughlin DJ, Healy RA, Kumar TKA, McLaughlin EG, Shirouzu T, Binder M (2016) Cultural and cytological characterization of Dacryopinax primogenitus, a new species in the Dacrymycetes with a fully sequenced genome. Mycologia 108: 457-468. https://doi.org/10.3852/15-229

17. McNabb RFR (1964) Taxonomic studies in the Dacrymycetaceae I. Cerinomyces Martin. New Zealand Journal of Botany 2: 415-424. https://doi.org/10.1080/0028825x.1964.10428762

18. McNabb RFR (1965a) Taxonomic studies in the Dacrymycetaceae. III. Dacryopinax Martin. New Zealand Journal of Botany 3: 59- 72. https://doi.org/10.1080/0028825X.1965.10432062

19. McNabb RFR (1965b) Taxonomic studies in the Dacrymycetaceae IV. Guepiniopsis Patouillard. New Zealand Journal of Botany 3: 159-169. https://doi.org/10.1080/0028825x.1965.10876992

20. McNabb RFR (1965c) Taxonomic studies in the Dacrymycetaceae V. Heterotextus Lloyd. New Zealand Journal of Botany 3: 215-222. https://doi.org/10.1080/0028825x.1965.10428722

21. McNabb RFR (1965d) Taxonomic studies in the Dacrymycetaceae VI. Femsjonia Fries. New Zealand Journal of Botany 3: 223-228. https://doi.org/10.1080/0028825x.1965.10428723

22. McNabb RFR (1965e) Taxonomic studies in the Dacrymycetaceae. II. Calocera (Fries) Fries. New Zealand Journal of Botany 3: 31-58. https://doi.org/10.1080/0028825X.1965.10428712

23. McNabb RFR (1966) Taxonomic studies in the Dacrymycetaceae VIl. Ditiola Fries. New Zealand Journal of Botany 4: 546-558. https:// doi.org/10.1080/0028825x.1966.10430183

24. McNabb RFR (1973) Taxonomic studies in the Dacrymycetaceae. VIII. Dacrymyces Nees ex Fries. New Zealand Journal of Botany 11: 461-524. https://doi.org/10.1080/0028825X.1973.10430296

25. Meijer AAR (2016). Preliminary list of the macromycetes from Brazilian state of Paraná. Boletim fo Museu Botânico Municipal, 68:1-55.

26. Miettinen O, Spirin V, Niemela T (2012) Notes on the genus Aporpium (Auriculariales, Basidiomycota), with a new species from temperate Europe. Ann. Bot. Fenn. 49: 359-368. doi: 
10.5735/085.049.0607.

27. Nees Von Esenbeck CGD (1816) Das System der Pilze and Schwämme. Vol. 2. Würzburg, 329 pp. https://doi.org/10.5962/bhl.title.46990

28. Nguyen L-T, Schmidt HA, Haeseler A von, Minh BQ (2015) IQ-TREE: A fast and effective stochastic algorithm for estimating maximum likelihood phylogenies. Mol Biol Evol, 32:268-274. https://doi.org/10.1093/molbev/msu300

29. Oberwinkler F (1993) Genera in a monophyletic group: The Dacrymycetales. Mycologia Helvetica 6: 35-72.

30. Oberwinkler F (2014) Dacrymycetes. In: McLaughlin, D.J. \& Spatafora, J.W. (Eds.) The Mycota VII. Systematics and Evolution, Part A. Springer-Verlag, Berlin, pp. 357-372. https://doi.org/10.1007/978-3-642-55318-9_13

31. Rambaut A (2014) FigTree v. 1.4.2. Available at <http://tree.bio.ed.ac.uk/software/figtree/>

32. Rambaut A, Drummond AJ, Xie D, et al (2018) Posterior Summarization in Bayesian Phylogenetics Using Tracer 1.7. Syst Biol 67:901-904. https://doi.org/10.1093/sysbio/syy032

33. Ronquist F, Huelsenbeck JP (2003) Mrbayes 3: bayesian phylogenetic inference under mixed models. Bioinformatics 19: 1572-1574. https://doi.org/10.1093/bioinformatics/btg180

34. Seifert KA. 1983. Decay of wood by the Dacrymycetales. Mycologia 75: 1011-1018

35. Shirouzu T, Hirose D, Oberwinkler F, Shimomura N, Maekawa N, Tokumasu S (2013) Combined molecular and morphological data for improving phylogenetic hypothesis in Dacrymycetes. Mycologia 105: 1110-1125. https://doi.org/10.3852/12-147

36. Shirouzu T, Hirose D, Tokumasu S (2009) Taxonomic study of the Japanese Dacrymycetes. Persoonia 23: 16-34. https://doi.org/10.3767/003158509X468443

37. Shirouzu T, Hosaka K, Nam KO, Weir BS, Johnston PR, Hosoya T (2017) Phylogenetic relationships of eight new Dacrymycetes collected from New Zealand. Persoonia 38: 156-169. https://doi.org/10.3767/003158517X695280

38. Sierra S, Cifuentes J (2005) A new species of Dacryopinax from Mexico. Mycotaxon 92: 243-250.

39. Sobestiansky G (2005) Contribution to a Macromycete Survey on the States of Rio Grande do Sul and Santa Catarina in Brazil. Braz. Arch. Biol. Technol. 48 (3): 437-457. https://doi.org/10.1590/S1516-89132005000300015

40. Sotão HMP, Campos EL, Costa SPSE, Melo OA, Azevedo JC (2002) Basidiomycetes macroscópicos de manguezais de Bragança, Pará, Brasil. Hoehnea 29: 215-224

41. Staden R, Beal KF, Bonfield JK (1998) The Staden Package. Computer Methods in Molecular Biology. Bioinformatics Methods and Protocols 132: 115-130.

42. Tamura K, Stecher G, Peterson D, Filipski A, Kumar S. (2013) MEGA6: molecular evolutionary genetics analysis version 6.0. Mol. Biol. and Evol. 30: 2725-2729. doi: 10.1093/molbev/mst197.

43. Thiers, B. (2016 [continuously updated]) Index Herbariorum: a global directory of public herbaria and associated staff. New York Botanical Garden's Virtual Herbarium. Available from: 
http://sweetgum.nybg.org/science/ih/ (accessed 20 September 2021)

https://doi.org/10.3897/biss.2.26440

44. Trifinopoulos J, Nguyen LT, von Haeseler A, Minh BQ (2016) W-IQ-TREE: a fast online phylogenetic tool for maximum likelihood analysis. Nucleic Acids Res 44(W1):W232-W235. https://doi.org/10.1093/nar/gkw256

45. Vilgalys R, Hester M (1990) Rapid genetic identification and mapping of enzymatically amplified DNA from several Cryptococcus species. Journal of Bacteriology 172: 4238-4246. https://doi.org/10.1128/JB.172.8.4238-4246.1990

46. Wells K (1994) Jelly fungi, then and now! Mycologia 86: 18-48. https://doi.org/10.2307/3760717

47. White TJ, Bruns T, Lee S, Taylor J (1990) Amplification and direct sequencing of fungal ribosomal RNA genes for phylogenetics. In: Innis MA, Gelfand DH, Sninsky JJ, White TJ (Eds) PCR protocols: a guide to methods and applications. Academic press, San Diego, 315-322. https://doi.org/10.1016/B978-0-12-372180-8.50042-1

48. Zamora JC, Ekman S (2020) Phylogeny and character evolution in the Dacrymycetes, and systematics of Unilacrymaceae and Dacryonaemataceae fam. nov. Persoonia 44, 2020: 161-205. https://doi.org/10.3767/persoonia.2020.44.07

\section{Table}

Due to technical limitations, table xlsx is only available as a download in the Supplemental Files section.

\section{Figures}



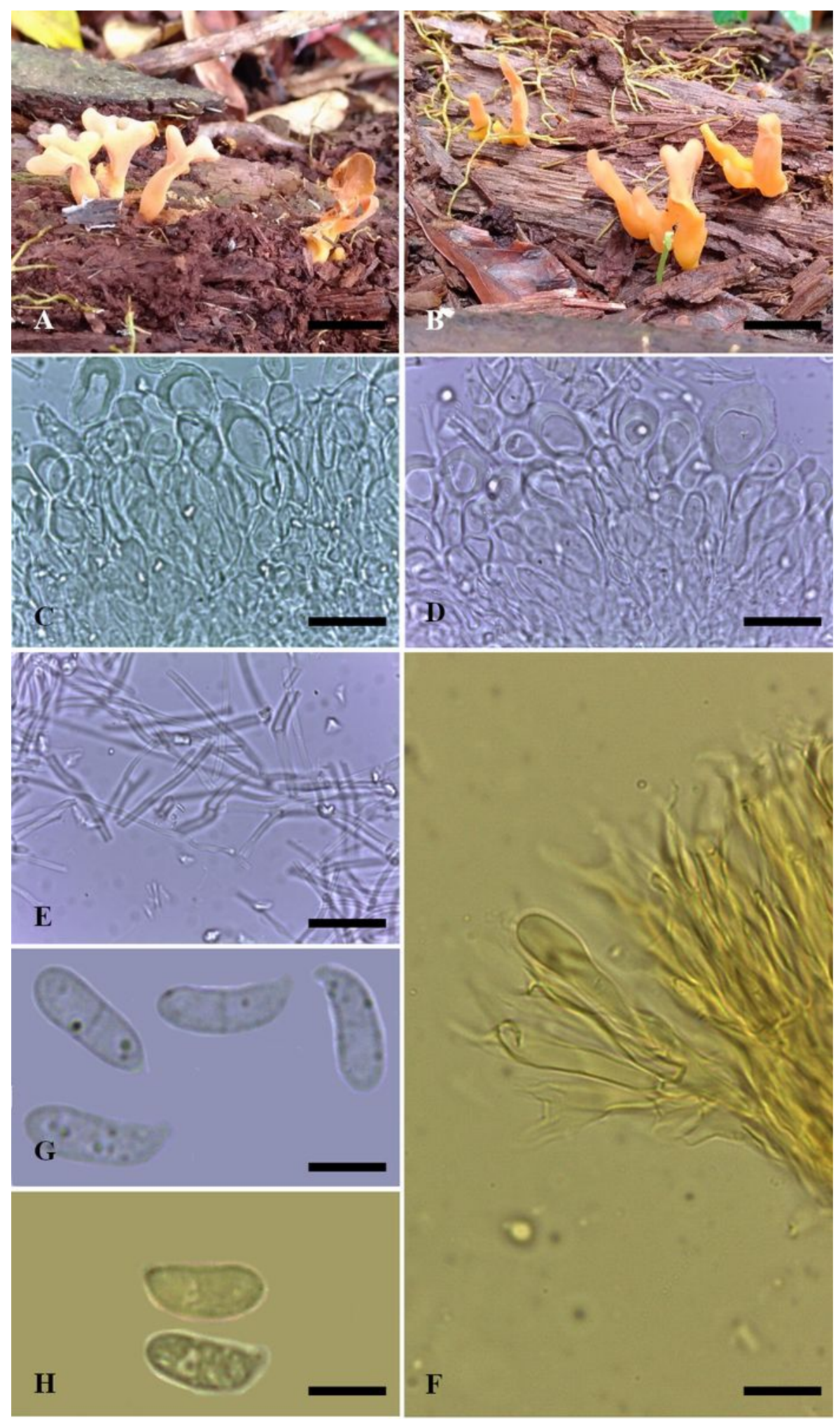

\section{Figure 1}

Phylogenetic reconstruction of sequences of Dacrymycetes specimens inferred from a combined dataset of ITS and nLSU. Branches are labeled with ML bootstrap and UFBoot2 equal to or higher than $70 \%$, and BI posterior probabilities equal to or higher than 0.95 respectively. The sequences in bold were generated in this study. The tree was rooted with Corpinus comatus (ALFTOL626) and Suillus pictus (AFTOL717) following Shirouzu et al. (2017). 


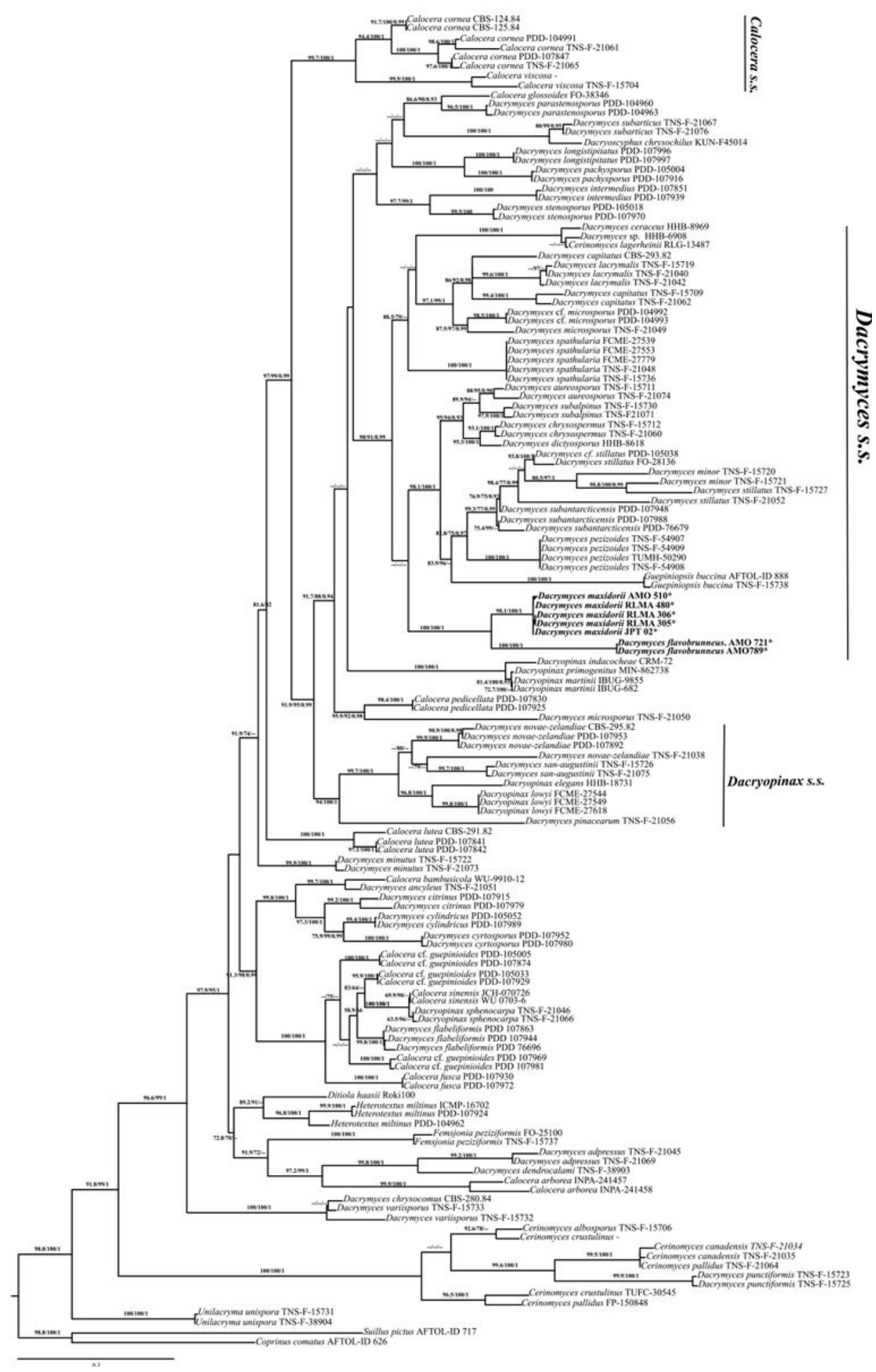

Figure 2

Dacrymyces flavobrunneus Alvarenga sp. nov. a-b. Fresh specimens (AM0789, URM XXXX); c-d. Abhymenium hairs; e. Heterogeneous context (hypha); f. Hymenium; g-h. Basidiospores ( $\mathrm{g}-$ in water, $\mathrm{h}-$ in Melzer's Solucion. Bars: $a, b=1 \mathrm{~cm} ; \mathrm{c}, \mathrm{d}, \mathrm{e}, \mathrm{f}=10 \mu \mathrm{m} ; \mathrm{g}, \mathrm{h}=5 \mu \mathrm{m}$

\section{Supplementary Files}


This is a list of supplementary files associated with this preprint. Click to download.

- Table1.xlsx 